Јелена Ранђеловић

Интернационални универзитет

Нови Пазар

Високошколска јединица Прешево
УДК 821.163.41.09 Андрић И. ДОИ https://doi.org/10.18485/ ai_lik.2016.2.3.2

\title{
НИКОЛАЈ ТИМЧЕНКО О ИВИ АНДРИЋУ
}

Рад има за циљ да осветли и прикаже интересовање Николаја Тимченка за стваралаштво Иве Андрића. Намера је да се анализом Тимченкових радова истакну стваралачки циклуси, проблеми и питања која су Николаја Тимченка подстицала да проучава Андрићево дело више од тридесет година. Посебна пажња је посвећена анализи естетских, теоријских, етичких, егзистенцијалних и метафизичких питања која је Тимченко проналазио у Андрићевом опусу и на основу њих преиспитивао природу књижевне творевине и стварања као највеће потврде човекове егзистенције.

Кључне речи: стваралаштво, књижевно дело, поетика, егзистенција, метод

Библиографија Николаја Тимченка ${ }^{1}$ сведочи да је он био свестрани стваралац, да су га окупирала различита питања, појаве и проблеми из књижевности и уметности. Посебно, његова пажња била је усмерена на књижевну критику и есејистику. У том широком пољу деловања приметне су теме које су биле Тимченкова духовна преокупација. Међу њима, значајно место заузима интересовање за стваралаштво Иве Андрића. Такође, библиографија показује да се Тимченково интересовање за дело поменутог нобеловца јавило већ са првим његовим текстовима, и да је трајало током целокупног његовог радног века.

1 Видети: Дејан Вукићевић, Библиоірафија Николаја Тимченка, Задужбина „Николај Тимченко“ / Лесковачки културни центар, Лесковац 2008. 
Радови који су настајали у периоду од преко тридесет година најбоље документују ову тврдњу: „Нови радови о Андрићу“ (1963), „Историја и поезија“ (1969), „Стваралац и дело“ (1969), „Запис о страху и људској дужности“ (1969), „Метафизички квалитет у делу Иве Андрића“ (1972), „Белешке о Андрићевом примеру“ (1977), „Пред делом Иве Андрића“ (1979), „Уметничко и хронолошко време у Травничкој хронищи“ (1980), „Иво Андрић у Срйском кюижевном іласнику“ (1987), „Роман или збирка прича“ (1995) „Два записа из Знакова йореg йyйа“ (1997), „Андрић у својим писмима“"(2000). ${ }^{2}$

Тимченково интересовање за Андрићево дело може се груписати у три стваралачка циклуса. Први циклус посвећен је разматрању изворног стваралаштва Иве Андрића. Други круг обухвата Андрићева дела објављена из заоставштине (поезија, збирка прича Кућа на осами, Знакови йореg йуйа, незавршени роман Омерӣаша Лайас). Трећи круг представљају текстови којима Тимченко, као савременик, прати књиге у којима су тумачена остварења Иве Андрића и метакритички текстови. ${ }^{3}$

Идући трагом Андрићевих идеја, Николаја Тимченка интересовали су бројни проблеми и питања која је Андрић својим делима отварао. Међу овим питањима издвајају се она која се тичу саме природе књижевне творевине, али и начина интерпретације појединачних егзистенцијалних проблема.

У првом кругу сустичу се питања која одувек заокупљују пажњу естетичара и теоретичара књижевности. Андрићев пример и уметничко дело полазна су тачка Тимченковом

2 Неке од наведених текстова Николај Тимченко је више пута објављивао у различитим часописима. Нови радови доносили су најчешће измене стилске природе, али постоје и радови у којима је Тимченко проширивао првобитну верзију новим сегментима, како би додатно осветлио и продубио исти проблем. Сви наведени радови, осим у бројним часописима и листовима, могу се пронаћи и у књизи Између стиваралашйва и еізистиениије, коју су 2011. године приредили Биљана и Владимир Мичић а објавила ју је Задужбина „Николај Тимченко“ - Лесковац.

3 Николај Тимченко пратио је и појављивање књижевнокритичких књига о Иви Андрићу. 
испитивању односа историје и уметности, начина претварања историјског у уметничку слику и исказ, могућности постојања уметничког лика, односа хронолошког и уметничког времена, односа историјске грађе и уметничке имагинације, социјалне и историјске условљености књижевног дела.

Естетским феноменом настајања књижевног дела, теоријским разматрањем претварања историјске грађе у поезију и формулисањем уметничког лика у Андрићевом делу Николај Тимченко се бавио у раду „Историја и поезија“. Промишљајући овај уметнички аспект аутор јасно истиче да се успешност уметничког лика и књижевног дела не дешава када се реконструише приватна историја историјске личности или некаквог прототипа, „већ када се ономе, што се догодило као појединачни случај, прида опште значење, па се тиме догађај у тренутку историје претвори у људско искуство сажето у поезији“ (стр. 15). ${ }^{4}$

У свом трагању за даљим објашњењем Тимченко разлаже овај процес настајања, задирући дубоко у општељудско искуство које потврђује егзистенцију човека:

„Када писац протекли доживљај оживи у уметничком облику, елиминишући приватни и пригодни моменат, а уопштавајући га до какве идеје о човековој суштини - његово дело постаје савремено; кидају се границе између прошлости и садашњости, које су ионако вештачке, и дело улази у општи фонд савремености, постаје уметнички документ о човеку за нас, а нађени завичај за свог творца“ (16).

Тематизујући проблем из наслова, аутор пресудну инстанцу за разумевање овог односа проналази у чињеници да се историја и поезија у уметничком делу искључују, те да „писац и не полази од историјског факта, јер га свесно пренебрегава као страно тело у организму свога дела. Пролазно не може чинити органску целину са оним што је по својој суштини надвременско и универзално“(16).

Однос историјских чињеница и њихова транспозиција у Травничкој хроници повод су да Тимченко проговори о односу хронолошког и уметничког времена. За Николаја

4 Цитати се наводе према књизи: Николај Тимченко, Између сйварапашйва и еізистиеницје. 
Тимченка јасна је разлика између историјског времена ( прошлост, садашњост, будућност), времена као појма којим се бави физика или астрономија, и уметничког времена (времена књижевног дела). На тај начин он поставља јасну границу између историјског и уметничког, чија је основна карактеристика управо брисање разлике између прошлости и будућности. Писац вишеструко преображава стварност од које полази, стога књижевно дело не може да буде једноставна репродукција стварности.

Разлажући епизоде из поменутог романа Тимченко иде и даље: поставља питање како хронолошко време прелази у уметничко, са крајњим циљем да покаже да је хронолошко време декор у коме се збива уметничко време. Резултате анализе коју је спровео Тимченко сажима, на крају, у једној реченици: „Кад оно субјективно добије адекватну уметничку форму, хронолошко време (које је по својој природи објективно) претвара се у уметничко време, и тако настаје књижевно дело“" (35).

Бављење мисаоном грађом открило је још једну важну особину Андрићевог дела - његову антрополошку димензију и вредност, чиме су антиципирани проблеми људске природе који сведоче о сличности појава у прошлости и садашњости, истовремено потврђујући и сведочанство једног континуитета.

Формулисањем претходних питања Тимченко је у свом истраживачком подухвату назначио и егзистенцијалну метафизику која прати тај и такав подухват, обједињујући естетске чиниоце дела с етичкометафизичким на којима се дело темељи.

На овај начин у први план избио је проблем бивања човека, потом проблем страха као егзистенцијалне категорије и основног човековог осећања, проблем ослобођења личности, затим проблем односа ауторитарне силе и слободе мишљења, и на крају проблем човековог права на побуну, као потврда његовог идентитета.

Тимченко у Андрићевом делу проналази битне одговоре на питање да ли је могуће човеково бивање, и у коликој мери, јер, како каже: „Андрићево дело је не само документ о 
стваралачком таленту свога творца него и монумент о човековим стваралачким моћима уопште“ (39).

Предмет разматрања у Тимченковим студијама о Андрићу јесу и уметник као друштвено ангажовани појединац и његово дело као егзистенцијално сведочанство универзалног карактера.

С тим у вези Николај Тимченко поставља питање које су дужности ствараоца у временима окупације земље: да ли ламентације о страху и злу, или супротстављање и једном и другом.

Ствараоцу остаје његово дело; Андрић га ствара с уверењем да је све пролазно, у првом реду зло и страх, да се све руши и нестаје, па и зло, а да остаје човек са својим људским дилемама, недоумицама и могућностима да ствара.

У тежњи ка стварању дела, ма у којој области, Тимченко види смисао људског бивања и једини начин за реализацију човековог у човеку, јер дело зато и постоји: да успостави мостове, да каже истину о животу, да исприча историју постојања човека уопште, и свог ствараоца посебно: „Нема ничег поузданог у животу, сем људског дела које надживљује свог ствараоца и своје савременике, омогућујући људима неопходну наду у сопствено очовечење“ $(43,44)$.

Не одвајајући естетику од етике, Тимченко нам показује како Андрићево дело, креирајући своју причу, трагајући за људским суштинама, врши двоструку функцију: служи човеку да пронађе себе и свој завичај и омогућује свом творцу да постоји као човек.

Питање људског стварања је, отуда, у најдубљој вези с питањем смисла човековог постојања, јер где има стваралаштва, ту се показује сама творачка човекова бит.

Маркирањем страха као једне од егзистенцијалних човекових ситуација, Андрић ће у Ex pontu записати: „Од страха су људи зли и сурови и подли, од страха су дарежљиви, чак и добри. Све се нижи вишега боји. А онај који нема никога да се боји, тај преза пред страхом ког му рађа његова болесна машта, јер страх је као зараза која испуњава све мозгове.“

Полазећи са назначеног становишта Тимченко прати Андрићеве ликове у разним животним ситуацијама под 
дејством овога механизма. То га доводи до закључка да „човек из страха и у страху често губи људско достојанство, претвара се у нечовека, у роба, у објект, у створење којим се манипулише. Такву ситуацију користе носиоци зла у свету и узурпирају слободу, ону човекову вредност које се он, у страху, веома често одриче“ (54).

Решење овог егзистенцијалног стања и проблема Николај Тимченко проналази у неопходности да се човек уздигне до своје личне слободе и дође до сазнања о свом основном људском праву - права на побуну. Оваква филозофија изискује снагу личности, слободне и индивидуалне, која ће рећи „не“, и издвојити се од масе. Па ипак, јасно је и самоме Тимченку да је човеку ретко успевало да буде слободно биће, и да примери из историје показују да то „не“није изговарано увек кад треба.

Одређујући, пак, карактер метафизичког квалитета у делу Иве Андрића, Тимченко препознаје прастари механизам деловања трагичког по коме зло делује онда када људско није у стању да се оствари. У томе човек је увек на губитку. Тај и такав механизам присутан је у приповеткама („Проба“, „Бифе Титаник“...), али и у Проклетиој авлији. Пораз човека у судару с емпиријском стварношћу прераста у метафизички квалитет трагичног, при чему трагику чини потпуна победа пролазне емпирије над духовним вредностима живота. Дакле, основну поруку која извире из Андрићевог дела Тимченко обухвата филозофијом песимистичке оријентације, и дефинише је на следећи начин: „Увек бољи губи, и увек доживљује пораз оно што је умно и што има већу људску вредност“" (101).

Андрићева дела објављена из заоставштине отварају други круг тема којима се Николај Тимченко бавио пратећи рад нашег нобеловца. Ови текстови драгоцени су као аутентичан извор за анализу поетике Иве Андрића, и уводе у саму срж „неисцрпно богате стваралачке радионице“.

Најважнија питања која Тимченко поставља у овом кругу јесу: у коликој и каквој мери и смислу посмртно објављена дела писца допуњују или мењају представу о његовом целокупном опусу, на који начин ваља посматрати и 
анализирати Андрића као лиричара, какав је однос збирке прича Кућа на осами у односу на остале приповедне збирке из његовог опуса, и како оквир романа Омерйаша Лайас допуњује слику Андрића као романописца.

Тимченко дакле трага за променама у стваралачком путу Иве Андрића, издвајајући доказе о природи и видовима пишчеве еволуције у његовом уметничком поступку, јер, како примећује, Андрић је био заокупљен проблемом књижевног поступка, смислом приповедања и функцијом уметности. У анализи текста Николај Тимченко приповедању приступа као саставном елементу прозе, а приповедни поступак основни је елеменат на основу кога изриче вредносни суд.

У томе аналитичком процесу аутор јасно примећује лук који полази од саме уметникове личности (лирика), удаљује се у лику објективног хроничара (романи), да би се затворио у исту стваралачку личност са почетка, у уводном делу Куће на осами.

Андрићева лирика за Тимченка представља врсту интимних записа у којима доминира исповедни тон и који сведочи о психичком стању пишчевом и о његовој поетици. Суђење о песниковој природи на основу његове поезије утицало је на Андрића да се дистанцира од свога дела и постане нека врста „објективног и свевидећег хроничара“.

Трагајући даље за суштином уметничког поступкаТимченко у уводном тексту збирке Кућа на осами препознаје повратак Иве Андрића сопственим почецима: писац више није сакривен иза „објективног хроничара“, већ је поново „непосредно“ пред читаоцем, у дијалогу са својим ликовима.

Андрић примењује модификован књижевни поступак, а његова занимљивост, како је види Николај Тимченко, јесте управо у чињеници да је у уводу збирке осмислио оквир којим је потпуно приближио писца и његове ликове, док је средишње причање задржало особине познатог Андрићевог поступка.

Сличности проналази Тимченко и у приповедном поступку између романа објављених за живота аутора и недовршеног романа постхумно штампаног. Па ипак, запажа 
да и ту Андрић одлази корак даље у тражењу израза. О томе сведочи разбијена композиција романа Омерӣаша Латиас, где се поједина поглавља могу читати и као засебне приповедачке целине.

За испитивање Андрићеве поетике, као и односа уметника према грађи својих остварења, Тимченко није заобишао ни Андрићеве есеје, пре свега оне о Вуку Караџићу и есеј „Разговор са Гојом“.

Иво Андрић је с посебном пажњом пратио дух, облик и технику Вуковог књижевног израза; трагом тих испитивања Тимченко закључује да је Андрић говорећи о Вуку „имао у виду идеал писца који у хаосу живота и свој разноликости стварности којом је човек окружен, пре свега жели да сагледа ред и да своје поступке обасја разумом“ (122). Чежња за никад недосегнутим редом и поретком, разумом, рационалним и јасним сагледавањем ствари и људских односа једна је од основних порука коју Тимченко издваја у Андрићевом делу, а која би се с лакоћом могла приписати и његовој сопственој тежњи.

У есеју „Разговор са Гојом“ Николај Тимченко види Андрићев однос према есеју као књижевној форми, с једне стране, док, с друге, овај оглед о односу уметника и друштва ствара лик сликара који у структури есеја прича своју уметничку биографију, износећи поетику - у којој Тимченко препознаје погледе самога Андрића. Пре свега, то је став да „смисао не треба тражити у само привидно важним догађајима из наше стварности, већ у легендама и у бајкама у којима је права историја човечанства“ (121).

Посебну скупину текстова сачињавају они у којима Тимченко као савременик прати појављивање књижевнокритичких књига о Андрићу.

О Сабраним gелима Иве Анgрића (1976) Тимченко каже да је то најпотпуније издање дела нашег нобеловца, и да се издавачима, упркос томе што им се могу ставити озбиљне примедбе, морају упутити речи хвале.

Сарадња Иве Андрића у Срйском књижевном іласнику осветљена из визуре Николаја Тимченка показала је да она представља важан део његове стваралачке биографије. Сазнајемо да је Андрић управо у Гласнику објавио више приповедака, међу 
њима и неке од најбољих остварења, да се ту огледао и као есејиста и као „непретенциозни“ккитичар, али и као хроничар књижевних и друштвено-политичких проблема.

Николај Тимченко је позитивно испратио и појаву књиге На сунчаној стирани, коју је приредила Жанета Ђукић Перишић, истичући да је реч о подухвату који „обогаћује и актуелизује колико Андрићево дело, толико и књижевнотеоријске проблеме у вези са њим“ (168).

Тимченкову пажњу посебно су привукле две књиге које су се појавиле поводом прославе седамдесетогодишњице

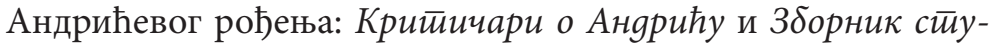
guја и чланака, у редакцији Војислава Ђурића.

Прва му је послужила да напомене да о писцу који је добио Нобелову награду и у чију вредност нико није сумњао, постоји „неуобичајено мали број критичких и есејистичких радова који би могли да уђу у један репрезентативни зборник студија и есеја о његовом делу“ (209). У другој књизи, која садржи двадесет два прилога, Тимченко проналази радове који представљају трајан допринос познавању Андрићевог опуса, али и есеје и чланке који не доносе ништа ново. Најсветлији тренутак у књизи, по речима Николаја Тимченка, јесте есеј Иве Тартаље „Есеји и записи Иве Андрића“, док Хергешићев прилог „Нобелове награде за књижевност и први наш књижевни нобеловац“ оцењује као текст који не заслужује своје место у зборнику.

Већ само набрајање проблема које је запазио Николај Тимченко у делу Иве Андрића, сведочи о његовој свестраној истраживачкој природи, али и аналитичности у раду. Ништа мање значајну карактеристику ових истраживања представља усредсређеност на питања о којима се расправља уз посебну стратегију методолошких и логичко-философских тумачења.

С тим у вези немогуће је не уочити карактеристичан Тимченков есејистички поступак: најпре се представља проблем и износе претпоставке, потом се издваја епизода или део на коме се проверавају претпоставке, проналазе се аргументи у делу и литератури, при чему Тимченко често прави дигресије. На крају овог поступка доноси се закључак и јасно исказан став. 
Иако Тимченков поступак и приступ данас није тако актуелан, његови закључци то свакако јесу. Задирање у суштину разматраних дела, али и у питања суштине егзистенције савременог човека, потврда су огромног знања заговорника плурализма метода, ширине културе истраживача и смисла за битне вредности уметности и културе.

Радови о Иви Андрићу представљају веома важну целину у Тимченковом критичком сагледавању прозе 20. века, и од изузетног су значаја за обликовање његовог стваралачког профила. У њима упознајемо Тимченка као писца из чијих радова подједнако говори дух ауторов, али и дух писаца, критичара, мислилаца чија дела анализира, такође и дух и смисао самих дела, као крајњег исходишта уметности и културе у чијем се кругу и догађа стварање као највиши смисао и потврда човековог постојања.

\section{Извори и литература}

Андрић Иво. Сабрана gела 1-20. Штампар Макарије, 2011.

Вукићевић Дејан. Библиоірафија Николаја Тимченка. Лесковац: Задужбина „Николај Тимченко“ / Лесковачки културни центар, 2008.

Timčenko Nikolaj. „Novi radovi o Andriću“. Delo, god. 9, knj. 9, br. 6 (jun 1963): 807-811.

Тимченко Николај. „Проблеми бивања човека у Андрићевој приповеци 'Зеко'“. Граяина, год. 3, бр. 6-7 (јун-јул 1968): 64-70.

Timčenko Nikolaj. „Stvaralački akt u Andrićevom delu“. Putevi, god. 14, br. 4 (juli-avgust 1968): 345- 355.

Тимченко Николај. „Запис о кмету Симану“. Браничево, год. 14, св. 5-6 (септембар-децембар 1968): 20-21.

Тимченко Николај. Песник и завичај: белешке о бивағу човека у титерераиури. Крушевац: Багдала, 1969.

Тимченко Николај. „Запис о страху и људској дужности : (над фрагментима АндрићевеПрозе). Браничево, год. 15, бр. 1-2 (јануар-април 1969): 14-19.

Тимченко Николај. „Метафизички квалитет у делу Иве Андрића“. Баїgала, год. 14, бр. 164 (новембар 1972): 2-4.

Timčenko Nikolaj. „Andrić u svetlu kritike“. Savremenik, god. 23, knj. 46, br. 8-9 (avgust-septembar 1977): 193-194. 
Timčenko Nikolaj. „Beleške o Andrićevom primeru“. Savremenik, god. 23, knj. 46, br. 11 (novembar 1977): 361-370.

Тимченко Николај. „На маргинама Андрићевог дела“. Баїgала, год. 19, бр. 225 (децембар 1977): 8-11.

Timčenko Nikolaj. „Pred delom Ive Andrića“. Izraz, god. 23, knj. 45, br. 6 (jun 1979): 475-487.

Timčenko Nikolaj. „Umetničko i hronološko vreme u Travničkoj hronici: (skica za studiju)“. Travnik i djelo Ive Andrića. Sarajevo: „Veselin Masleša“, 1980.

Тимченко Николај. „Естетско и етичко у књижевном делу“. Граgина, год. 22, 6р. 4 (април 1987): 23-28.

Тимченко Николај. „Иво Андрић у Срйском књижевном іласнику“. Сйремльеньа, год. 27, бр. 3 (мај-јун 1987): 34-47.

Тимченко Николај. „Роман или збирка прича“. Нама реч, год. 51, 6р. 19 (19. мај 1995): 12.

Тимченко Николај. „Два записа из Знакова йореg йуйа“. Помак, год. 2, бр. 3-4 (1997): 4.

Тимченко Николај. „Андрић у својим писмима“. Помак, год. 5, бр. 17-18 (октобар-децембар 2000): 30.

Тимченко Николај. Између сииваралашиева и еізисиенције: О Aнgрuћy u Црњанском. Лесковац: Задужбина „Николај Тимченко“, 2011.

\section{Jelena Ranđelović}

\section{TIMCHENKO ABOUT ANDRIC}

\section{Summary}

The paper aims to shed light and display interest of Nikolai Timchenko for the creation of Ivo Andric. The intention is to highlight creative cycles, problems and issues that have encouraged Nikolai Timchenko to study of Andric's work for more than thirty years by analyzing Timchenko papers. Special attention is devoted to the analysis of esthetical, theoretical, ethical, existential and metaphysical questions that Timchenko finding in Andric's papers and on the basis of them questioned the nature of literary work and the creation as the greatest confirmation of human existence. 